CLINICAL STUDY

\title{
More than adequate iodine intake may increase subclinical hypothyroidism and autoimmune thyroiditis: a cross-sectional study based on two Chinese communities with different iodine intake levels
}

\author{
Xiaochun Teng ${ }^{1}$, Zhongyan Shan ${ }^{1}$, Yanyan $\mathrm{Chen}^{2}$, Yaxin Lai ${ }^{1}$, Jiashu $\mathrm{Yu}^{2}$, Ling Shan ${ }^{2}, \mathrm{Xue} \mathrm{Bai}^{2}$, Yuanbin $\mathrm{Li}^{2}$, \\ Ningna $\mathrm{Li}^{2}$, Zhidan $\mathrm{Li}^{2}$, Sen Wang ${ }^{2}$, Qian Xing ${ }^{2}$, Haibo Xue ${ }^{2}$, Lin Zhu ${ }^{2}$, Xin $\mathrm{Hou}^{2}$, Chenling Fan ${ }^{2}$ and \\ Weiping Teng ${ }^{2}$ \\ ${ }^{1}$ Department of Endocrinology and Metabolism and ${ }^{2}$ Liaoning Key Laboratory of Endocrine Diseases, Institute of Endocrinology, The First Affiliated \\ Hospital, China Medical University, No 155 Nanjing Bei Street, Heping District, Shenyang, People's Republic of China \\ (Correspondence should be addressed to W Teng; Email: twpendocrine@yahoo.com.cn; X Teng; Email: tengxiaochun@126.com)
}

\begin{abstract}
Objective: With the introduction of iodized salt worldwide, more and more people are exposed to more than adequate iodine intake levels with median urinary iodine excretion (MUI 200-300 $\mu \mathrm{g} / \mathrm{l}$ ) or excessive iodine intake levels (MUI $>300 \mu \mathrm{g} / \mathrm{l}$ ). The objective of this study was to explore the associations between more than adequate iodine intake levels and the development of thyroid diseases (e.g. thyroid dysfunction, thyroid autoimmunity, and thyroid structure) in two Chinese populations. Design: A population-based cross-sectional study was conducted in two areas in which people are exposed to different levels of iodine intake (Rongxing, MUI $261 \mu \mathrm{g} / \mathrm{l}$; Chengshan, MUI $145 \mu \mathrm{g} / \mathrm{l}$ ). A total of 3813 individuals were recruited by random sampling. Thyroid hormones, thyroid autoantibodies in serum, and iodine levels in urine were measured. B-mode ultrasonography of the thyroid was also performed for each participant.

Results: The prevalence of subclinical hypothyroidism was significantly higher for subjects who live in Rongxing than those who live in Chengshan ( 5.03 vs $1.99 \%, P<0.001)$. The prevalence of positive anti-thyroid peroxidase antibody (TPOAb) and positive anti-thyroglobulin antibody ( $\mathrm{TgAb})$ was significantly higher for subjects in Rongxing than those in Chengshan (TPOAb: 10.64 vs $8.4 \%$, $P=0.02$; TgAb: 10.27 vs $7.93 \%, P=0.01)$. The increase in thyroid antibodies was most pronounced in the high concentrations of TPOAb (TPOAb: $\geq 500 \mathrm{IU} / \mathrm{ml}$ ) and low concentrations of $\mathrm{TgAb}$ (TgAb: 40-99 IU/ml) in Rongxing.

Conclusions: More than adequate iodine intake could be a public health concern in terms of thyroid function and thyroid autoimmunity in the Chinese populations.
\end{abstract}

European Journal of Endocrinology $164943-950$

\section{Introduction}

Iodine is essential to maintain a normal thyroid function. Iodine deficiency can result in thyroid goiter and hypothyroidism (1). On the other hand, excessive iodine intake can also lead to thyroid dysfunction. For instance, high iodine intake in China due to the presence of high iodine in drinking water or in Japan due to high seaweed consumption (milligram of iodine intake per day) has been linked with thyroid disorders such as goiter, hypothyroidism, and autoimmune thyroiditis (2-6). In iodine-deficient areas, increase in iodine intake might precipitate iodine-induced hyperthyroidism (7-10).

In 1990, the goal of the World Summit for Children at the United Nations was to eliminate iodine deficiency diseases and recommended universal salt iodization (USI) as the main strategy (11). The introduction of iodine fortification of salt and the appearance of various iodine fortifications in food greatly improved the iodine nutritional status worldwide. In 2003, the WHO released a report on using USI from 126 countries. There were 54 countries reporting iodine deficiency, 43 reporting adequate (median urinary iodine excretion (MUI) 100-200 $\mu \mathrm{g} / \mathrm{l}), 24$ reporting more than adequate (MUI 200-300 $\mu \mathrm{g} / \mathrm{l}$ ), and five reporting excessive iodine intake level (MUI > $300 \mu \mathrm{g} / \mathrm{l}$ ). Of the 72 countries that reported having sufficient iodine intake levels, $40.3 \%$ had MUI levels exceeding the optimal range recommended by international organizations (12). USI was initially introduced in China in 1996. National monitoring data show that Chinese inhabitants 
experienced excessive iodine intake during the period 1997-2001 and more than adequate iodine intake after $2001(13,14)$.

In 2001, WHO/UNICEF/ICCIDD reported that ingestion of iodine at a more than adequate level may lead to the development of iodine-induced hyperthyroidism in susceptible groups within 5-10 years following the introduction of iodized salt $(7,9,15)$. Other effects such as iodine-induced hypothyroidism and iodine-induced autoimmune thyroiditis were not reported. We conducted a 5-year follow-up study (from 1999 to 2004), and our data showed that among three communities in China with an MUI of $84 \mu \mathrm{g} / \mathrm{l}$ (a mildly deficient iodine intake area), $243 \mu \mathrm{g} / \mathrm{l}$ (a more than adequate iodine intake area), and $651 \mu \mathrm{g} / \mathrm{l}$ (an excessive iodine intake area), the incidence of either hypothyroidism or autoimmune thyroiditis increased with the increased intake levels $(16,17)$. Unfortunately, at that time, we had no data from an area with adequate iodine intake.

The objective of this study was to answer the following question: compared with iodine adequacy, does intake of a more than an adequate level of iodine influence thyroid function, thyroid autoimmunity, and goiter? In 2007, we chose two areas with an MUI of 100-200 and 200-300 $\mu \mathrm{g} / \mathrm{l}$ respectively, and conducted a cross-sectional epidemiological study to explore the relationship between more than adequate iodine intake levels and the spectrum of thyroid diseases in the two Chinese populations.

\section{Subjects and methods}

\section{Subjects}

In 2007, two representative areas with different iodine intake levels were chosen for the study. Chengshan, a rural community located in the south of Liaoning Province, had mildly deficient levels of iodine intake before salt iodization (iodine content in drinking water was $4.3 \mu \mathrm{g} / \mathrm{l}$; MUI $61.67 \mu \mathrm{g} / \mathrm{l}$ in 1996) (18). However, the MUI during 1997-2007 was 120-155 $\mu \mathrm{g} / \mathrm{l}$ due to the introduction of salt iodization, and the iodine intake of the local inhabitants has been adequate (i.e. MUI 100-200 $\mu \mathrm{g} / \mathrm{l})$ since salt iodization began. Rongxing, another rural community located in the west of Liaoning Province, had no history of iodine deficiency before the introduction of salt iodization because of high iodine content in drinking water $(55.5 \mu \mathrm{g} / \mathrm{l}$; MUI $154.5 \mu \mathrm{g} / \mathrm{l}$ in 1994) (19). However, the MUI was increased to 200-300 $\mu \mathrm{g} / \mathrm{l}$ between 1996 and 2007 after salt iodization was instituted. Thus, it is possible that iodine intake has been more than adequate (i.e. MUI 200-300 $\mu \mathrm{g} / \mathrm{l}$ ) since salt iodization was introduced in the area. Geographically, there are more than $400 \mathrm{~km}$ between the two communities. The difference in iodine intake levels between the two areas is due to the different levels of iodine in drinking water (Table 1).

In the first part of this study, home visits were performed to register the local inhabitants who had lived in the study areas for more than 10 years, and onethird of the residents in each area participated in this study. Pregnant women, women who had given birth within the past year, and women taking oral contraceptives were excluded, as were persons receiving glucocorticoids, dopamine, or anti-epileptic drugs and persons diagnosed as having renal insufficiency or adrenocortical hypofunction. In total, 3813 people were enrolled in this study (1908 in Rongxing and 1905 in Chengshan). In Chengshan and Rongxing, 19 and 23 persons respectively, had a history of overt hyperthyroidism, who had received one or more of the treatments such as anti-thyroid drugs, radioiodine treatment, and thyroid surgery; one person in Chengshan and three persons in Rongxing were previously diagnosed as having overt hypothyroidism and had been taking levothyroxine; and 84 persons in Chengshan and 99 persons in Rongxing had the family history of thyroid diseases, with no significant difference found between the two populations ( 4.4 vs $5.2 \%, \chi^{2}=1.27, P=0.26$ ). The demographic characteristics of the two populations with different levels of iodine intake are shown in Table 1 and Fig. 1. Both the sex and the age composition of the two populations were similar. Smokers accounted for $36 \%$ of the population in Rongxing and 35\% in Chengshan (smoker: one or more than one cigarette per day, continuous or cumulative smoking for 6 months or more). People with a history of alcohol intake accounted for $36 \%$ of the population in Rongxing and 32\% in Chengshan (drinker: $20 \mathrm{~g}$ or more than $20 \mathrm{~g}$ alcohol intake per day, continuous alcohol intake for 1 year or more). For each participant, both palpation and B-mode

Table 1 Demographic characteristics and trace element levels in the two populations with adequate iodine intake levels and more than adequate iodine intake levels. Values are presented as mean \pm S.D.

\begin{tabular}{lll}
\hline Characteristic & Chengshan $^{\mathrm{a}}$ & Rongxing $^{\mathrm{b}}$ \\
\hline Sample size & 1905 & 1908 \\
Sex (M:F) & $1: 1.67$ & $1: 1.76$ \\
Age & $47.26 \pm 15.96$ & $46.32 \pm 15.85$ \\
U iodine $(\mu \mathrm{g} / \mathrm{l} ;$ median (IQR)) & & \\
$\quad$ Schoolchildren & & \\
$\quad$ Study populations & & \\
lodine in salt $(\mathrm{mg} / \mathrm{kg} ; n=20)$ & $145(88-229)$ & $261(201-342)$ \\
lodine in drinking water & $25.6 \pm 4.3$ & $24.3 \pm 3.5$ \\
$\quad(\mu g / / ; ; n=20)$ & $1.7-4.5$ & $55.4-60.5$ \\
Serum selenium $(\mu \mathrm{g} / \mathrm{l} ; n=60)$ & $79.88 \pm 13.09$ & $80.75 \pm 13.89$ \\
Serum zinc $(\mathrm{mg} / \mathrm{l} ; n=60)$ & $0.81 \pm 0.14$ & $0.79 \pm 0.09$ \\
$\quad$ Urinary fluorine $(\mathrm{mg} / \mathrm{l} ; n=100)$ & $0.56 \pm 0.12$ & $0.62 \pm 0.18$ \\
\hline
\end{tabular}

IQR, interquartile range; $U$ iodine, urinary iodine.

${ }^{a}$ Adequate iodine intake.

${ }^{\mathrm{b}}$ More than adequate iodine intake.

'Data from schoolchildren aged 8-10 years old in each community $(n=80)$.

dData from study populations in each community $(n=585$ in Rongxing; $n=582$ in Chengshan). 

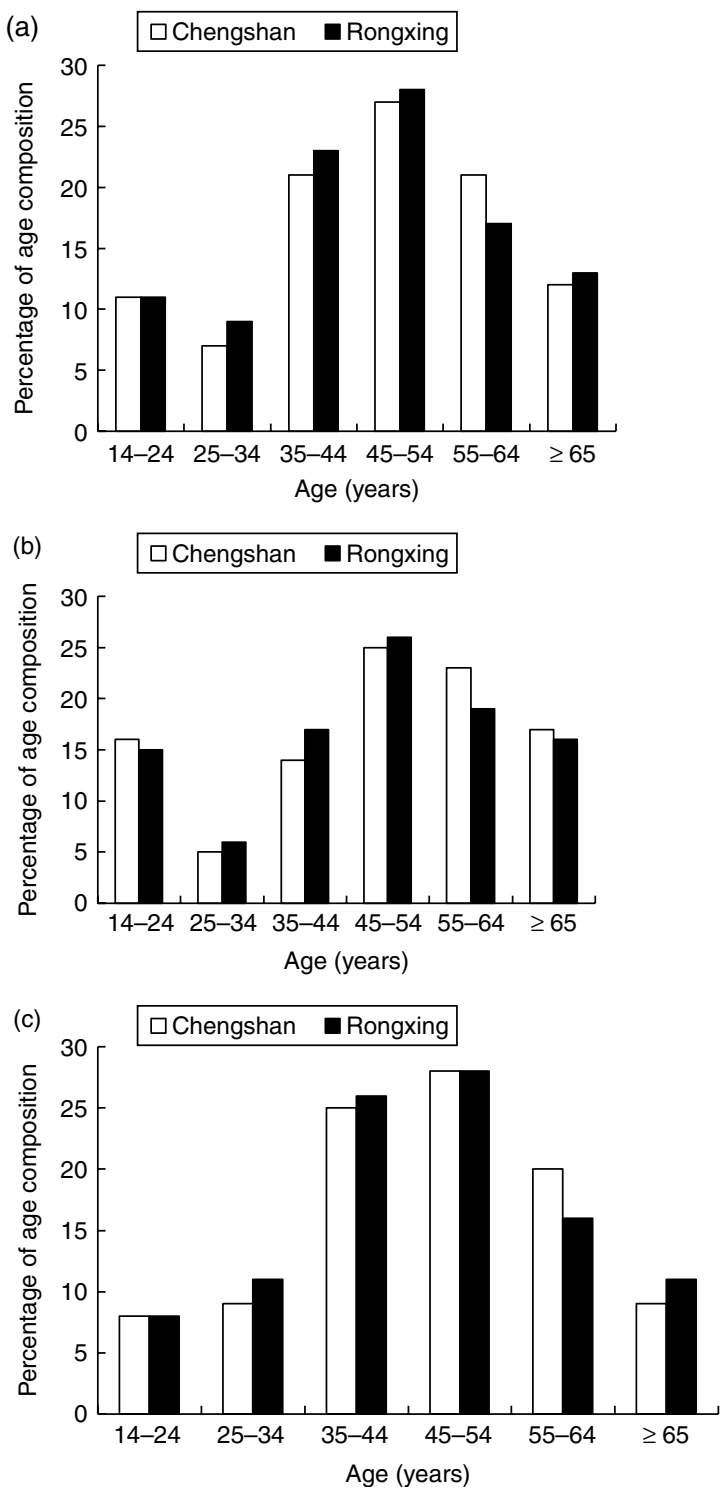

Figure 1 Age composition of the two populations with different levels of iodine intake. The age composition of the two populations was similar, and no significant difference was detected between them for (a) the whole population, (b) males only, and (c) females only.

ultrasonography of the thyroid were performed, and samples of fasting urine and blood were obtained.

The research protocols were approved by the medical ethics committee of China Medical University. All subjects provided written informed consent after the study was explained to them during the recruitment process.

\section{Assays}

Serum TSH, thyroid peroxidase antibody (TPOAb), and thyroglobulin antibody ( $\mathrm{TgAb})$ were measured in all participants, and free thyroxine $\left(\mathrm{FT}_{4}\right)$ and free tri-iodothyronine $\left(\mathrm{FT}_{3}\right)$ levels were determined in subjects with abnormal TSH. These were measured using a solid-phase, enzyme-labeled, chemiluminescent sequential immunometric assay (IMMULITE 1000 Analyzer, Diagnostic Products Corporation, Los Angeles, CA, USA). The reference range of serum TSH (0.3-4.8 mIU/l) was derived from the 2.5th-97.5th percentile in 2503 normal subjects with no family or personal history of thyroid disease, normal serum thyroid autoantibody values, and no goiter or nodules detected under B-mode ultrasound (16). The sensitivity of serum TSH was $0.002 \mathrm{mIU} / \mathrm{l}$. The intra- and interassay coefficients of variation for serum parameters were as follows: TSH: $2.5 \%, 2.2 \%$ at $0.26 \mathrm{mIU} / \mathrm{l}$ and $3.2 \%, 1.2 \%$ at $4.06 \mathrm{mIU} / \mathrm{l}$; TPOAb (reference range: 7-50 IU/ml defined by our laboratory): $3.3 \%, 4.3 \%$ at $42.5 \mathrm{IU} / \mathrm{ml}$ and $5.7 \%, 2.9 \%$ at $516.5 \mathrm{IU} / \mathrm{ml}$; $\mathrm{TgAb}$ (reference range: $10-40 \mathrm{IU} / \mathrm{ml}$ defined by our laboratory): $4.1 \%, 3.4 \%$ at $33.7 \mathrm{IU} / \mathrm{ml}$ and $4.6 \%$, $2.9 \%$ at $517.6 \mathrm{IU} / \mathrm{ml} ; \mathrm{FT}_{4}$ (reference range of kit: $10.3-24.5 \mathrm{pmol} / \mathrm{l}): 5.7 \%, 3.2 \%$ at $10.65 \mathrm{pmol} / \mathrm{l}$ and $3.4 \%, 3.1 \%$ at $30.55 \mathrm{pmol} / \mathrm{l}$; and $\mathrm{FT}_{3}$ (reference range of kit: $2.3-6.3 \mathrm{pmol} / \mathrm{l}): 5.5 \%, 1.7 \%$ at $4.85 \mathrm{pmol} / \mathrm{l}$ and $4.2 \%, 3.9 \%$ at $17.38 \mathrm{pmol} / \mathrm{l}$ respectively.

Urinary iodine concentration was determined in all participants by the ammonium persulfate method based on the Sandell-Kolthoff reaction (20). Considering that some other trace elements such as selenium, zinc, and fluorine are involved in the development of thyroid function, thyroid autoimmunity, and goiter (21-24), 60 serum samples from each population were randomly selected and the levels of serum selenium, serum zinc, and urinary fluorine were measured. Urinary fluorine concentrations were measured by fluorine ion-selective electrode. Serum selenium concentrations were measured by inductively coupled plasma atomic emission spectrometry, and serum zinc concentrations were measured by atom absorption method. No significant difference was found in the levels of serum selenium, serum zinc, and urinary fluorine between the two populations (Table 1). We also did not find an association between serum selenium levels and the titers of thyroid autoantibodies. The inter- and intraassay coefficients of variation of serum selenium, serum zinc, and urinary fluorine were $<6 \%$.

Thyroid ultrasonography was performed by two trained observers using a portable instrument (LOGIQ $\alpha 50$, GE, Milwaukee, WI, USA with $7.5 \mathrm{MHz}$ linear transducers). The normal thyroid volume was obtained from healthy subjects residing in Chengshan (MUI $145 \mu \mathrm{g} / \mathrm{l}$ ) without known thyroid disease; without a family history of thyroid disease; without anti-thyroid antibodies; and without goiter, nodules, or an abnormal echo pattern on B-mode ultrasonography. Goiter was defined as a thyroid volume exceeding $22.5 \mathrm{ml}$ for women and $25.4 \mathrm{ml}$ for men, which corresponded to the mean (+2 S.D.) in 478 healthy male subjects and 596 female subjects. The diagnostic criteria for thyroid diseases are listed in Table $2(16,25)$. 
Table 2 Diagnostic criteria for thyroid diseases. The reference range of serum TSH $(0.3-4.8 \mathrm{mIU} / \mathrm{l})$ was derived from the 2.5th-97.5th percentile in 2503 normal subjects (16) (no family or personal thyroid disease, normal serum thyroid autoantibody values, and no goiter or nodules under B-mode ultrasound).

\begin{tabular}{|c|c|}
\hline Thyroid disease & Diagnostic criteria \\
\hline Overt hypothyroidism & $\mathrm{TSH}>4.8 \mathrm{mlU} / \mathrm{l}$, free $\mathrm{T}_{4}<10.3 \mathrm{pmol} / \mathrm{l}$ \\
\hline $\begin{array}{l}\text { Subclinical } \\
\text { hypothyroidism }\end{array}$ & $\begin{array}{l}\mathrm{TSH}>4.8 \mathrm{mlU} / \mathrm{l} \text {, free } \mathrm{T}_{4} \text { levels within the } \\
\text { normal range }\end{array}$ \\
\hline $\begin{array}{l}\text { High serum } \\
\text { autoantibody values }\end{array}$ & TPOAb $\geq 50 \mathrm{IU} / \mathrm{ml}$ or $\mathrm{TgAb} \geq 40 \mathrm{IU} / \mathrm{ml}$ \\
\hline Overt hyperthyroidism & $\begin{array}{l}\mathrm{TSH}<0.3 \mathrm{mlU} / \mathrm{l}, \text { free } \mathrm{T}_{4}>24.5 \mathrm{pmol} / \mathrm{l} \\
\text { and } / \text { or free } \mathrm{T}_{3}>6.3 \mathrm{pmol} / \mathrm{l}\end{array}$ \\
\hline Graves' disease & $\begin{array}{l}\text { Overt hyperthyroidism, a diffuse goiter } \\
\text { or normal thyroid volume on B-mode } \\
\text { ultrasonography }\end{array}$ \\
\hline Toxic nodular goiter & $\begin{array}{l}\text { Overt hyperthyroidism with nodular } \\
\text { goiter }\end{array}$ \\
\hline $\begin{array}{l}\text { Subclinical } \\
\text { hyperthyroidism }\end{array}$ & $\begin{array}{l}\mathrm{TSH}<0.3 \mathrm{mlU} / \mathrm{l} \text {, free } \mathrm{T}_{4} \text { and free } \\
\mathrm{T}_{3} \text { within the normal ranges }\end{array}$ \\
\hline Goiter & $\begin{array}{l}\text { Thyroid volume }>22.5 \mathrm{ml} \text { (women) or } \\
>25.4 \mathrm{ml} \text { (men) }\end{array}$ \\
\hline & Goiter without nodules \\
\hline Nodular goiter & Goiter with nodules $>10 \mathrm{~mm}$ in diameter \\
\hline
\end{tabular}

Free $T_{4}$, reference range of kit: 10.3-24.5 pmol/l. Free $T_{3}$, reference range of kit: $2.3-6.3 \mathrm{pmol} / \mathrm{l}$. TPOAb, thyroid peroxidase antibody, reference range: $7-50 \mathrm{IU} / \mathrm{ml}$ defined by our laboratory; $\mathrm{TgAb}$, thyroglobulin antibody, reference range: $10-40 \mathrm{IU} / \mathrm{ml}$ defined by our laboratory.

\section{Statistical analysis}

All statistical analyses were performed using SPSS software (version 11.5; SPSS, Inc., Chicago, IL, USA). The proportions were compared using a $\chi^{2}$ test. The mean values for continuous variables, like age, were tested using a $t$-test. The level of significance was set at $5 \%$ for both the $\chi^{2}$ test and the $t$-test.

\section{Results}

\section{Hypothyroidism}

In Chengshan, three patients were diagnosed as having overt hypothyroidism. Among them, one had a history of overt hyperthyroidism and the other two were first diagnosed as having spontaneous overt hypothyroidism. In Rongxing, six patients were diagnosed as having overt hypothyroidism. Among them, two had thyroid adenoma and the remaining four were diagnosed as having spontaneous overt hypothyroidism. In Chengshan and Rongxing, 38 and 96 patients respectively, were newly diagnosed as having subclinical hypothyroidism. Thus, the prevalence of subclinical hypothyroidism was higher in subjects from Rongxing than in subjects from Chengshan $\left(\chi^{2}=24.52, P<0.000\right.$; Table 3). Among the 38 patients from Chengshan, three $(10 \%)$ were previously diagnosed as having clinical hypothyroidism and $16(42 \%)$ had positive thyroid autoantibodies. Among the 96 patients from Rongxing, ten (10\%) were being treated for hypothyroidism or receiving thyroid surgery for thyroid nodules and 35 (36\%) had positive thyroid autoantibodies. In total, thyroid autoimmunity accounted for more than $40 \%$ of subclinical hypothyroidism in both the populations.

\section{Hyperthyroidism}

In Chengshan, 34 patients were diagnosed as having overt hyperthyroidism (previously diagnosed: seven cases and newly diagnosed: 27 cases), whereas in Rongxing, 24 patients were diagnosed with this disorder (previously diagnosed: seven cases and newly diagnosed: 17 cases). Table 3 shows the prevalence of overt hyperthyroidism and Graves' disease (GD) in both the populations. GD was the main cause of overt hyperthyroidism, accounting for $53 \%$ of the cases in Chengshan and $66.7 \%$ in Rongxing. Toxic nodular goiter was the cause of hyperthyroidism in five cases in Chengshan and one case in Rongxing. Thus there was no significant difference between the two populations. The prevalence of subclinical hyperthyroidism was $1.73 \%$ in Chengshan and $0.63 \%$ in Rongxing $\left(\chi^{2}=9.95, P=0.002\right)$. Of the 142 cases with subclinical hyperthyroidism, no significant difference in the positive rate of TPOAb was found between the two areas.

\section{Thyroid autoantibodies}

The prevalence of both positive TPOAb and positive $\mathrm{TgAb}$ was higher in Rongxing than in Chengshan (TPOAb: $\chi^{2}=5.55, P=0.02$; TgAb: $\chi^{2}=6.34, P=0.01$; Table 3). Then we divided the positive TPOAb into low level (TPOAb: 50-99 IU/ml), middle level (TPOAb: 100-299 IU/ml), middle-high level (TPOAb: 300$499 \mathrm{IU} / \mathrm{ml}$ ), and high level (TPOAb: $\geq 500 \mathrm{IU} / \mathrm{ml}$ ), as well as positive TgAb into low level (TgAb:

Table 3 The prevalence of thyroid diseases in the two populations with adequate iodine intake levels and more than adequate iodine intake levels.

\begin{tabular}{lrcl}
\hline & \multicolumn{2}{c}{ Prevalence of diseases $(n(\%))$} & \\
\cline { 2 - 3 } & $\begin{array}{c}\text { Chengshan }^{\mathrm{a}} \\
n=1905\end{array}$ & $\begin{array}{c}\text { Rongxing } \\
n=1908\end{array}$ & \multicolumn{1}{c}{$\boldsymbol{P}$} \\
\hline Hypothyroidism & $41(2.15)$ & $102(5.35)$ & $<0.000$ \\
Overt & $3(0.16)$ & $6(0.31)$ & $\mathrm{NS}^{*}$ \\
Subclinical & $38(1.99)$ & $96(5.03)$ & $<0.000$ \\
Hyperthyroidism & $67(3.52)$ & $36(1.89)$ & 0.002 \\
Overt & $34(1.78)$ & $24(1.26)$ & $\mathrm{NS}$ \\
Graves' disease & $18(1.31)$ & $16(0.94)$ & $\mathrm{NS}$ \\
Subclinical & $33(1.73)$ & $12(0.63)$ & 0.002 \\
Positive TPOAb & $160(8.39)$ & $203(10.64)$ & 0.02 \\
Positive TgAb & $151(7.93)$ & $196(10.27)$ & 0.01 \\
Goiter & $174(9.13)$ & $137(7.18)$ & 0.03 \\
Diffuse & $79(4.15)$ & $85(4.45)$ & $\mathrm{NS}$ \\
Nodular & $89(4.67)$ & $47(2.46)$ & $<0.001$ \\
\end{tabular}

*Not statistically significant at $P=0.05$. TPOAb, thyroid peroxidase antibody, reference range: $7-50 \mathrm{lU} / \mathrm{ml}$ defined by our laboratory; $\mathrm{TgAb}$, thyroglobulin antibody, reference range: $10-40 \mathrm{lU} / \mathrm{ml}$ defined by our laboratory.

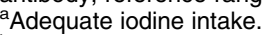

${ }^{\mathrm{b}}$ More than adequate iodine intake. 
Table 4 Comparison of serum-positive thyroid autoantibody concentrations in the two populations with adequate and more than adequate iodine intake levels.

\begin{tabular}{lccc}
\hline $\begin{array}{l}\text { Serum-positive } \\
\text { thyroid autoanti- } \\
\text { body concen- } \\
\text { tration (IU/ml) }\end{array}$ & $\begin{array}{c}\text { Chengshan } \\
n=1905\end{array}$ & $\begin{array}{c}\text { Rongxing } \\
n=1908\end{array}$ & $\boldsymbol{P}$ \\
\hline TPOAb $(n(\%))$ & $25(1.31)$ & $31(1.62)$ & $\mathrm{NS}^{\text {b }}$ \\
$50-99$ & $44(2.31)$ & $54(2.83)$ & $\mathrm{NS}$ \\
$100-299$ & $26(1.36)$ & $27(1.42)$ & $\mathrm{NS}$ \\
$300-499$ & $65(3.41)$ & $91(4.77)$ & 0.034 \\
$\geq 500$ & & & \\
TgAb $(n(\%))$ & $48(2.52)$ & $87(4.56)$ & $<0.001$ \\
$40-99$ & $51(2.68)$ & $43(2.25)$ & $\mathrm{NS}$ \\
$100-299$ & $19(0.99)$ & $24(1.26)$ & $\mathrm{NS}$ \\
$300-499$ & $33(1.73)$ & $42(2.20)$ & $\mathrm{NS}$ \\
$\geq 500$ & & & \\
\hline
\end{tabular}

*Not statistically significant at $P=0.05$ level. TPOAb, thyroid peroxidase antibody; $\mathrm{TgAb}$, thyroglobulin antibody.

${ }^{a}$ Adequate iodine intake.

${ }^{\mathrm{b}}$ More than adequate iodine intake.

40-99 IU/ml), middle level (TgAb: 100-299 IU/ml), middle-high level (TgAb: 300-499 IU/ml), and high level $(\mathrm{TgAb}: \geq 500 \mathrm{IU} / \mathrm{ml})$. We found that high concentrations of TPOAb or low concentrations of $\operatorname{TgAb}$ were more frequent in Rongxing than in Chengshan (TPOAb: $\chi^{2}=4.48, P=0.03$; $\mathrm{TgAb}$ : $\chi^{2}=11.62, P<0.001$; Table 4$)$.

\section{Goiter}

The prevalence of goiter was higher in Chengshan than in Rongxing $\left(\chi^{2}=4.85, P=0.03\right)$. When we analyzed the cause of goiter, we found that the prevalence of nodular goiter was higher in Chengshan than in Rongxing $\left(\chi^{2}=12.44, P<0.001\right)$, but no significant difference was found in diffuse goiter between the two populations (Table 3). In patients with diffuse goiter, the rate of positive thyroid autoantibodies was higher in Rongxing than in Chengshan (51.8 vs 35.4\%, $\chi^{2}=4.43, P=0.035$ ), indicating that thyroid autoimmunity may be involved in the formation of diffuse goiter in more than adequate iodine intake areas. However, no significant difference was found in the rate of positive thyroid autoantibodies in 160 patients with nodular goiter $(20.2 \%$ in Chengshan versus $19.1 \%$ in Rongxing, $P>0.05)$.

\section{Discussion}

This study focused on the impact of more than adequate iodine intake on thyroid diseases in the Chinese populations. Compared with the adequate iodine intake level recommended by WHO/UNICEF/ICCIDD MUI $(100-200 \mu \mathrm{g} / \mathrm{l})$, our data indicated that MUI 200-300 $\mu \mathrm{g} / \mathrm{l}$ might be related to potentially increased risk of developing subclinical hypothyroidism or autoimmune thyroiditis. This result differs from the WHO's suggestion that MUI $>300 \mu \mathrm{g} / \mathrm{l}$ may increase the risk of developing autoimmune thyroid diseases (15).

In both the 5-year follow-up study and this study, we found that high iodine intake was associated with a significant increase in the prevalence of hypothyroidism. The acute Wolff-Chaikoff effect $(26,27)$ suggested that iodine-induced hypothyroidism, especially occurring in patients on amiodarone therapy, is caused by failure of the thyroid gland to escape from acute inhibition $(28,29)$. However, the exact mechanism by which chronic high iodine intake induces hypothyroidism remains unclear. Vitale et al. (30) and our previous experimental studies revealed that high iodine intake damages endogenous thyroid peroxidase and induces apoptosis in these cells through a mechanism that involves the generation of free radicals (30-32), but whether the iodine-induced apoptosis contributes to chronic iodine-induced hypothyroidism is unknown. It has been reported that iodine-induced hypothyroidism usually resolves quickly after iodine withdrawal, but if the administration of iodide continues, overt or subclinical hypothyroidism will persist (33). Even though the symptoms of subclinical hypothyroidism are less, complications can be severe. For example, subclinical hypothyroidism is not only an independent risk factor for coronary heart disease but it can also result in a poor neurodevelopmental outcome in a fetus or neonate during pregnancy (34-36). Thus, preventing high iodine-induced hypothyroidism is as important as preventing iodine deficiency-induced hypothyroidism.

Studies in both humans and animals have demonstrated that iodine administration may enhance autoimmune thyroiditis $(4,5,37-46)$. Totally, three mechanisms (47) have been assumed for the development of iodine-induced autoimmune thyroiditis. First, iodine intake increases the immunogenicity of thyroglobulin $(\mathrm{Tg})$, thereby precipitating an autoimmune process at both the T- and B-cell level (48-50). Secondly, iodine has a toxic effect on thyroid cells (51-53). Thirdly, iodine directly stimulates immune and immunity-related cells (54-56). Then what is the upper limit of iodine intake that could be considered a risk factor for iodine-induced autoimmune thyroiditis in humans? In Japan, the incidence of autoimmune thyroiditis is higher in areas with high dietary iodine intake (milligrams of iodine intake per day) than in areas with normal dietary iodine intake $(4,5)$. Our 5 -year prospective study has found that the cumulative incidence of autoimmune thyroiditis was higher in subjects with more than adequate iodine intake than in those with mild deficient iodine intake (16). In this study, we again confirmed that the prevalence of positive thyroid autoantibodies was higher in subjects with more than adequate iodine intake than in those with adequate iodine intake. So we infer that more than adequate iodine intake would be a risk factor for autoimmune thyroiditis in humans. 
Why the increase was more pronounced in the high concentrations of TPOAb and low concentrations of $\mathrm{TgAb}$ in the more than adequate iodine intake area deserves further observation. We will continue to follow up the dynamic change of the positive thyroid autoantibodies.

In this study, the prevalence of both overt hyperthyroidism and GD was similar between the two communities with MUI 145 and $261 \mu \mathrm{g} / \mathrm{l}$ respectively. GD was the main cause of overt hyperthyroidism in both the communities. Our 5-year follow-up study also reported that there was no difference in either the prevalence or the incidence of overt hyperthyroidism in areas with MUI of $84 \mu \mathrm{g} / \mathrm{l}$ (a mildly deficient iodine intake area), $243 \mu \mathrm{g} / \mathrm{l}$ (a more than adequate iodine intake area), and $651 \mu \mathrm{g} / \mathrm{l}$ (an excessive iodine intake area) $(57,58)$. Thus, from our epidemiological studies, we infer that excess chronic iodine would not increase the prevalence of overt hyperthyroidism.

Another interesting result is that we found a higher prevalence of nodular goiter in Chengshan (MUI $145 \mu \mathrm{g} / \mathrm{l}$ ), whereas higher positive thyroid autoantibodies were found in diffuse goiter in Rongxing (MUI $261 \mu \mathrm{g} / \mathrm{l})$. The explanation for the higher prevalence of nodular goiter may be connected with the iodinedeficient history in Chengshan. Urinary iodine levels can be quickly increased by iodine supplementation, but disappearance of nodular goiter is difficult to achieve $(20,59)$. The result that a higher positive thyroid autoantibodies were found in diffuse goiter in Rongxing indicated that when iodine nutrition shifted from iodine deficiency to more than adequate iodine, thyroid autoimmunity will be the main cause of diffuse goiter rather than in iodine deficiency.

Considering the effects of some confounding factors on the thyroid diseases, this study chose the comparative method to study the effect of iodine on the thyroid diseases, which excludes the effects of the confounding factors such as the sex and age composition of the populations, social and economic condition, the personal and family history of thyroid diseases, the condition of taking alcohol and smoking, and other trace elements (selenium, zinc, and fluorine). But there was shortage in choosing the adequate iodine intake area in this study. Chengshan was an area shifting from mild deficient iodine intake levels to adequate iodine intake levels since 1996, but not a long-term adequate iodine intake area. Because of the USI in China, it is difficult to find a stably adequate iodine intake area at present.

In conclusion, compared with the population with MUI $145 \mu \mathrm{g} / \mathrm{l}$ in Chengshan, the population with MUI $261 \mu \mathrm{g} / \mathrm{l}$ in Rongxing had a higher risk to develop autoimmune thyroiditis and subclinical hypothyroidism. Thus, more than adequate iodine intake might not be recommended for the general population in terms of keeping a normal function of thyroid.

\section{Declaration of interest}

The authors declare that there is no conflict of interest that could be perceived as prejudicing the impartiality of the research reported.

\section{Funding}

This study was supported by grants from the China Guanghua Foundation (grant numbers: China Guanghua Foundation 2007-2).

\section{Author contribution statement}

The authors' responsibilities were as follows $-\mathrm{X}$ Teng performed the study design, participated in the epidemiological study, and prepared the first version of the manuscript; Z Shan and W Teng performed the study design and participated in the discussion of the findings; $Y$ Chen, Y Lai, J Yu, L Shan, X Bai, Y Li, N Li, and Z Li participated in the epidemiological study and performed the statistical analysis; S Wang, Q Xing, H Xue, L Zhu, and X Hou participated in the epidemiological study; C Fan performed the measurements. None of the authors declared a conflict of interest.

\section{Acknowledgements}

We are indebted to the residents of Rongxing and Chengshan who participated in this study. We thank Jianhui Wang, Jinkuan Hao, and Zhongyuan Kan (Centers for Diseases Control and Prevention in Liaoning Province) for their administrative assistance and cooperation. We also thank Medjaden Bioscience Limited for assisting in the preparation of this manuscript.

\section{References}

1 Zimmermann MB, Jooste PL \& Pandav CS. Iodine-deficiency disorders. Lancet 2008372 1251-1262. (doi:10.1016/S01406736(08)61005-3)

2 Li M, Liu DR, Qu CY, Zhang PY, Qian QD, Zhang CD, Jia QZ, Wang MX, Eastman CJ, Boyages SC, Collins JK, Jupp JJ \& Maberly GF. Endemic goitre in Central China caused by excessive iodine intake. Lancet $19872257-259$.

3 Kim JY \& Kim KR. Dietary iodine intake and urinary iodine excretion in patients with thyroid diseases. Yonsei Medical Journal $20004122-28$

4 Inoue M, Taketani N, Sato T \& Nakajima H. High incidence of chronic lymphocytic thyroiditis in apparently healthy school children: epidemiological and clinical study. Endocrinologia Japonica 197522 483-488.

5 Konno N, Makita H, Yuri K, Iizuka N \& Kawasaki K. Association between dietary iodine intake and prevalence of subclinical hypothyroidism in the coastal regions of Japan. Journal of Clinical Endocrinology and Metabolism 199478 393-397. (doi:10.1210/jc. 78.2.393)

6 Konno N, Yuri K, Taguchi H, Miura K, Taguchi S, Hagiwara K \& Murakami S. Screening for thyroid diseases in an iodine sufficient area with sensitive thyrotrophin assays, and serum thyroid autoantibody and urinary iodide determinations. Clinical Endocrinology 199338 273-281. (doi:10.1111/j.1365-2265.1993. tb01006.x)

7 Stanbury JB, Ermans AE, Bourdoux P, Todd C, Oken E, Tonglet R, Vidor G, Braverman LE \& Medeiros-Neto G. Iodine-induced hyperthyroidism: occurrence and epidemiology. Thyroid $1998 \mathbf{8}$ 83-100. (doi:10.1089/thy.1998.8.83)

8 Bourdoux P, Ermans AM, Mukalay WA, Filetti S \& Vigneri R. Iodine induced thyrotoxicosis in Kiwu Zaire. Lancet $1996347552-553$. (doi:10.1016/S0140-6736(96)91188-5) 
9 Todd CH, Allain T, Gomo ZAR, Hasier JA, Ndiweni M \& Oken E. Increase in thyrotoxicosis associated with iodine supplements in Zimbabwe. Lancet 1995346 1563-1564. (doi:10.1016/S01406736(95)92095-1)

10 Delange F, de Benoist B \& Alnwick D. Risks of iodine-induced hyperthyroidism after correction of iodine deficiency by iodized salt. Thyroid 19999 545-556. (doi:10.1089/thy.1999.9.545)

11 WHO/UNICEF/ICCIDD. Indicators for Assessing Iodine Deficiency Disorders and their Control through Salt Iodization, pp 1-55. Geneva: WHO, 1994.

12 Iodine status worldwide. WHO Global Database on Iodine Deficiency pp 1-58. Geneva: Department of Nutrition for Health and Development World Health Organization, 2004.

13 Chen Z, Yan Y \& Shu Y. Analysis of iodine intake levels and safe range of iodine intake after universal salt iodization in China. Chinese Journal of Control of Endemic Diseases 200116 185-188.

14 Chen Z. Should we insist on monitoring iodine deficient disorders? Chinese Journal of Endemiology 200625 237-238.

15 WHO/UNICEF/ICCIDD. Assessment of Iodine Deficiency Disorders and Monitoring their Elimination. A Guide for Programme Managers. Geneva: World Health Organization, 2001.

16 Teng W, Shan Z, Teng X, Guan H, Li Y, Teng D, Jin Y, Yu X, Fan C, Chong W, Yang F, Dai H, Yu Y, Li J, Chen Y, Zhao D, Shi X, Hu F, Mao J, Gu X, Yang R, Tong Y, Wang W, Gao T \& Li C. Effect of iodine intake on thyroid diseases in China. New England Journal of Medicine 2006354 2783-2793. (doi:10.1056/NEJMoa054022)

17 Shan ZY, Li YS, Wang ZY, Jin Y, Guan HX, Hu FN, Teng XC, Yang F, Gao TS, Wang WB, Shi XG, Tong YJ, Chen W \& Teng WP. Effect of different iodine intake on the prevalence of hypothyroidism in 3 counties in China. Chinese Medical Journal 2005118 1918-1920.

18 Yao W, Lu DX \& Hao JK. The effect of different iodine intake status on children's psychomotor development. Chinese Journal of Control of Endemic Diseases 200015 58-59.

19 Wang JH, Gao R \& Liu Y. Influences of universal salt iodization on children's intelligence and psychomotor development. Chinese Journal of Public Health 200521 1054-1056.

20 WHO/UNICEF/ICCIDD. Assessment of Iodine Deficiency Disorders and Monitoring their Elimination. A Guide for Programme Managers. 3rd edition, pp 1-108, 2007.

21 Thurlow RA, Winichagoon P, Pongcharoen T, Gowachirapant S, Boonpraderm A, Manger MS, Bailey KB, Wasantwisut E \& Gibson RS. Risk of zinc, iodine and other micronutrient deficiencies among school children in North East Thailand. European Journal of Clinical Nutrition 2006 60 623-632. (doi:10. 1038/sj.ejcn.1602361)

22 Prummel MF, Strieder T \& Wiersinga WM. The environment and autoimmune thyroid diseases. European Journal of Endocrinology 2004150 605-618. (doi:10.1530/eje.0.1500605)

23 Burke G. Effects of thyrotropin, sodium fluoride and ions on thyroid metabolism. Metabolism 1970 19 35-42. (doi:10.1016/ 0026-0495(70)90115-0)

24 Gartner R, Gasnier BC, Dietrich JW, Krebs B \& Angstwurm MW. Selenium supplementation in patients with autoimmune thyroiditis decreases thyroid peroxidase antibodies concentrations. Journal of Clinical Endocrinology and Metabolism $2002 \mathbf{8 7}$ 1687-1691. (doi:10.1210/jc.87.4.1687)

25 Yu X, Fan C, Shan Z, Teng X, Guan H, Li Y, Teng D, Jin Y, Chong W, Yang F, Dai H, Yu Y, Li J, Chen Y, Zhao D, Shi X, Hu F, Mao J, Gu X, Yang R, Tong Y, Wang W, Gao T, Li C \& Teng W. A five-year followup study of goiter and thyroid nodules in three regions with different iodine intakes in China. Journal of Endocrinological Investigation 200831 243-250.

26 Wolff J, Chaikoff IL, Goldberg RC \& Meier JR. The temporary nature of the inhibitory action of excess iodide on organic iodine synthesis in the normal thyroid. Endocrinology $1949 \mathbf{4 5} 504-513$. (doi:10. 1210/endo-45-5-504)

27 Wolff J \& Chaikoff IL. Plasma inorganic iodide as a homeostatic regulator of thyroid function. Journal of Biological Chemistry 1948 74 $555-564$
28 Pitsiavas V, Smerdely P \& Boyages SC. Amiodarone compared with iodine exhibits a potent and persistent inhibitory effect on TSHstimulated cAMP production in vitro: a possible mechanism to explain amiodarone-induced hypothyroidism. European Journal of Endocrinology 1999140 241-249. (doi:10.1530/eje.0.1400241)

29 Theodoropoulos T, Braverman LE \& Vagenakis AG. Iodide-induced hypothyroidism: a potential hazard during perinatal life. Science 1979205 502-503. (doi:10.1126/science.451615)

30 Vitale M, Di Matola T, D’Ascoli F, Salzano S, Bogazzi F, Fenzi G, Martino E \& Rossi G. Iodide excess induces apoptosis in thyroid cells through a p53-independent mechanism involving oxidative stress. Endocrinology 2000141 598-605. (doi:10.1210/en.141.2.598)

31 Zhang N, Tong Y, Shan Z \& Teng W. Effect of chronic mild and moderate iodine excess on thyroid anti-oxidative ability of iodine deficiency and non-iodine deficiency Wistar rats. National Medical Journal of China $2006 \mathbf{8 6} 1274-1278$.

32 Man N, Guan H, Shan Z, Li Y, Fan C, Guo X, Chen W, Tong Y, Chong W, Mao J \& Teng W. Long-term effects of high iodine intake: inhibition of thyroid iodine uptake and organification in Wistar rats. National Medical Journal of China $2006863420-3424$.

33 Markou K, Georgopoulos N, Kyriazopoulou V \& Vagenakis AG. Iodine-induced hypothyroidism. Thyroid $2001 \mathbf{1 1}$ 501-510. (doi:10.1089/105072501300176462)

34 Haddow JE, Palomaki GE, Allan WC, Williams JR, Knight GJ, Gagnon J, O’Heir CE, Mitchell ML, Hermos RJ, Waisbren SE, Faix JD \& Klein RZ. Maternal thyroid deficiency during pregnancy and subsequent neuropsychological development of the child. New England Journal of Medicine 1999341 549-555. (doi:10. 1056/NEJM199908193410801)

35 Li Y, Shan Z, Teng W, Yu X, Li Y, Fan C, Teng X, Guo R, Wang H, Li J, Chen Y, Wang W, Chawinga M, Zhang L, Yang L, Zhao Y \& Hua T. Abnormalities of maternal thyroid function during pregnancy affect neuropsychological development of their children at 25-30 months. Clinical Endocrinology 201072 825-829. (doi:10.1111/j.1365-2265.2009.03743.x)

36 Hak AE, Pols HAP, Visser TJ, Drexhage HA, Hofman A \& Witteman JC. Subclinical hypothyroidism is an independent risk factor for atherosclerosis and myocardial infarction in elderly women: the Rotterdam Study. Annals of Internal Medicine 2000 132 270-278.

37 McConahey WM, Keating FR, Beahrs OH \& Woolner LB. On the increasing occurrence of Hashimoto's thyroiditis. Journal of Clinical Endocrinology and Metabolism 196222 542-544. (doi:10.1210/ jcem-22-5-542)

38 Weaver DK, Nishiyama RH, Burton WD \& Batsakis JG. Surgical thyroid disease. A survey before and after iodine prophylaxis. Archives of Surgery 196692 796-801.

39 Furszyfer J, Kurland LT, McConahey WM, Woolner LB \& Elveback LR. Epidemiologic aspects of Hashimoto thyroiditis and Graves' disease in Rochester, Minnesota (1935-1967), with special reference to temporal trends. Metabolism 197221 197204. (doi:10.1016/0026-0495(72)90041-8)

40 Laurberg P, Pedersen KM, Vestergaard H \& Sigurdsson G. High incidence of multinodular toxic goiter in the elderly population in a low iodine intake area vs high incidence of Graves' disease in the young in a high iodine intake area: comparative surveys of thyrotoxicosis epidemiology in East-Jutland Denmark and Iceland. Journal of Internal Medicine 1991229 415-420. (doi:10.1111/j. 1365-2796.1991.tb00368.x)

41 Papanastasiou L, Alevizaki M, Piperingos G, Mantzos E, TseleniBalafouta S \& Koutras DA. The effect of iodine administration on the development of thyroid autoimmunity in patients with nontoxic goiter. Thyroid 200010 493-497.

42 Fountoulakis S, Philippou G \& Tsatsoulis A. The role of iodine in the evolution of thyroid disease in Greece: from endemic goiter to thyroid autoimmunity. Hormones 20076 25-35.

43 Alsayed A, Gad AM, Abdel-Baset H, Abdel-Fattah A, Ahmed A \& Azab A. Excess urinary iodine is associated with autoimmune subclinical hypothyroidism among Egyptian women. Endocrine Journal 200855 601-605. (doi:10.1507/endocrj.K07E-165) 
44 Bagchi N, Brown TR, Urdanivia E \& Sundick RS. Induction of autoimmune thyroiditis in chickens by dietary iodine. Science 1985230 325-327. (doi:10.1126/science.4048936)

45 Allen EM, Appel MC \& Braverman LE. The effect of iodide ingestion on the development of spontaneous lymphocytic thyroiditis in the diabetes-prone BB/W rat. Endocrinology 1986118 1977-1981. (doi:10.1210/endo-118-5-1977)

46 Rasooly L, Burek CL \& Rose NR. Iodine induced autoimmune thyroiditis in NOD-H-2h4 mice. Clinical Immunology and Immunopathology 199681 287-292. (doi:10.1006/clin.1996.0191)

47 Papanastasiou L, Vatalas IA, Koutras DA \& Mastorakos G. Thyroid autoimmunity in the current iodine environment. Thyroid 2007 17 729-739. (doi:10.1089/thy.2006.0299)

48 Saboori AM, Rose NR, Bresler HS, Vladut-Talor M \& Burek CL. Iodination of human thyroglobulin (Tg) alters its immunoreactivity. I: Iodination alters multiple epitopes of human Tg. Clinical and Experimental Immunology 1998113 297-302. (doi:10.1046/j. 1365-2249.1998.00643.x)

49 Rasooly L, Rose NR, Saboori AM, Ladenson P \& Burek CL. Iodine is essential for human $\mathrm{T}$ cell recognition of human thyroglobulin. Autoimmunity 199827 213-219. (doi:10.3109/0891693980 8993833)

50 Sundick RS, Herdegen DM, Brown TR \& Bagchi N. The incorporation of dietary iodine into thyroglobulin increases its immunogenicity. Endocrinology 1987120 2078-2084. (doi:10. 1210/endo-120-5-2078)

51 Teng X, Shan Z, Teng W, Fan C, Wang H \& Guo R. Experimental study on the effects of chronic iodine excess on thyroid function, structure, and autoimmunity in autoimmune-prone NOD.H-2h4 mice. Clinical and Experimental Medicine 20099 51-59. (doi:10. 1007/s10238-008-0014-0)

52 Chen W, Teng X, Shan Z, Fan C, Guan H, Man N, Li Y, Tong Y, Chong $\mathrm{W} \&$ Teng $\mathrm{W}$. Chronic effects of excessive iodine intake on apoptosis of thyrocytes in Wistar rats. Chinese Journal of Endocrinology and Metabolism 200824 649-653.
53 Bagchi N, Brown TR \& Sundick RS. Thyroid cell injury is an initial event in the induction of autoimmune thyroiditis by iodine in obese strain chickens. Endocrinology 1995136 5054-5060. (doi:10.1210/en.136.11.5054)

54 Sharma RB, Alegria JD, Talor MV, Rose NR, Caturegli P \& Burek CL. Iodine and IFN-gamma synergistically enhance intercellular adhesion molecule 1 expression on NOD.H2h4 mouse thyrocytes. Journal of Immunology 2005 174 7740-7745.

55 Weetman AP, McGregor AM, Campbell H, Lazarus TH, Ibbertson HK \& Hall R. Iodide enhances IgG synthesis by human peripheral blood lymphocytes in vitro. Acta Endocrinologica 1983 103 210-215. (doi:10.1530/acta.0.1030210)

56 Davies TF, Yang C \& Platzer M. The influence of antithyroid drugs and iodide on thyroid cell MHC class II antigen expression. Clinical Endocrinology 198931 125-131. (doi:10.1111/j.1365-2265. 1989.tb01235.x)

57 Yang F, Teng W, Shan Z, Guan H, Li Y, Jin Y, Hu F, Shi X, Tong Y, Chen W, Yuan B, Wang Z, Cui B \& Yang S. Epidemiological survey on the relationship between different iodine intakes and the prevalence of hyperthyroidism. European Journal of Endocrinology 2002146 613-618. (doi:10.1530/eje.0.1460613)

58 Yang F, Shan Z, Teng X, Li Y, Guan H, Chong W, Teng D, Yu X, Fan C, Dai H, Yu Y, Yang R, Li J, Chen Y, Zhao D, Mao J \& Teng W. Chronic iodine excess does not increase the incidence of hyperthyroidism: a prospective community-based epidemiological survey in China. European Journal of Endocrinology 2007156 403-408. (doi:10.1530/EJE-06-0651)

59 Andersson M. Takkouche B, Egli I, Allen HE \& de Benoist B. Current global iodine status and progress over the last decade towards the elimination of iodine deficiency. Bulletin of the World Health Organization 200583 518-525.

Received 21 March 2011

Accepted 28 March 2011 